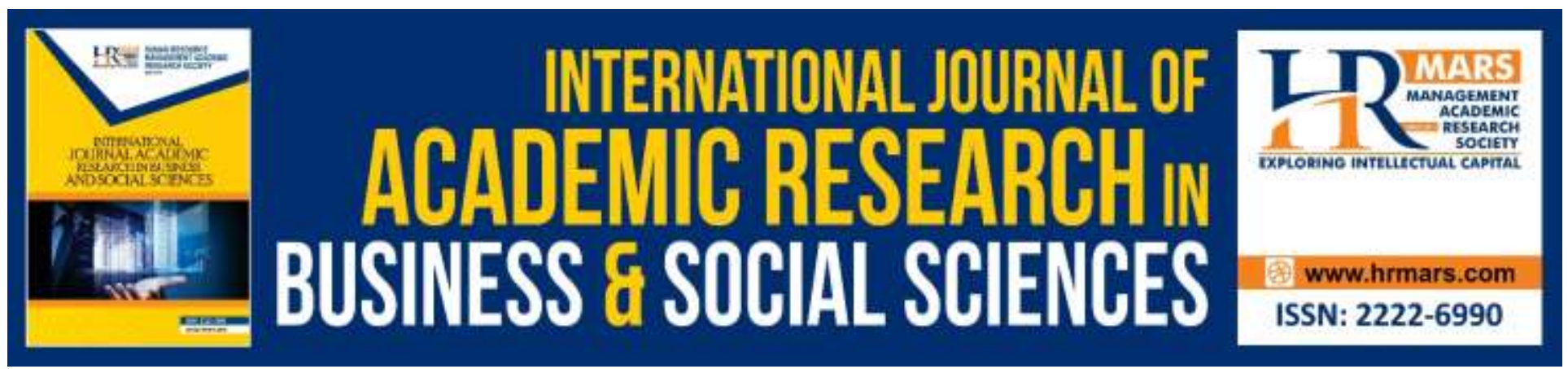

\title{
Forms and Content of Malaysian Indie Theatre in the Development of the Malay Drama
}

Syarul Azlina, Zolkipli Abdullah

To Link this Article: http://dx.doi.org/10.6007/IJARBSS/v10-i1/6851

DOI:10.6007/IJARBSS/v10-i1/6851

Received: 21 December 2019, Revised: 04 January 2020, Accepted: 21 January 2020

Published Online: 27 January 2020

In-Text Citation: (Azlina \& Abdullah, 2020)

To Cite this Article: Azlina, S., \& Abdullah, Z. (2020). Forms and Content of Malaysian Indie Theatre in the Development of the Malay Drama. International Journal of Academic Research in Business and Social Sciences, 10(1), 293-299.

Copyright: (C) 2020 The Author(s)

Published by Human Resource Management Academic Research Society (www.hrmars.com)

This article is published under the Creative Commons Attribution (CC BY 4.0) license. Anyone may reproduce, distribute, translate and create derivative works of this article (for both commercial and non-commercial purposes), subject to full attribution to the original publication and authors. The full terms of this license may be seen

at: http://creativecommons.org/licences/by/4.0/legalcode

Vol. 10, No. 1, 2020, Pg. 293 - 299

http://hrmars.com/index.php/pages/detail/IJARBSS

JOURNAL HOMEPAGE

Full Terms \& Conditions of access and use can be found at http://hrmars.com/index.php/pages/detail/publication-ethics 


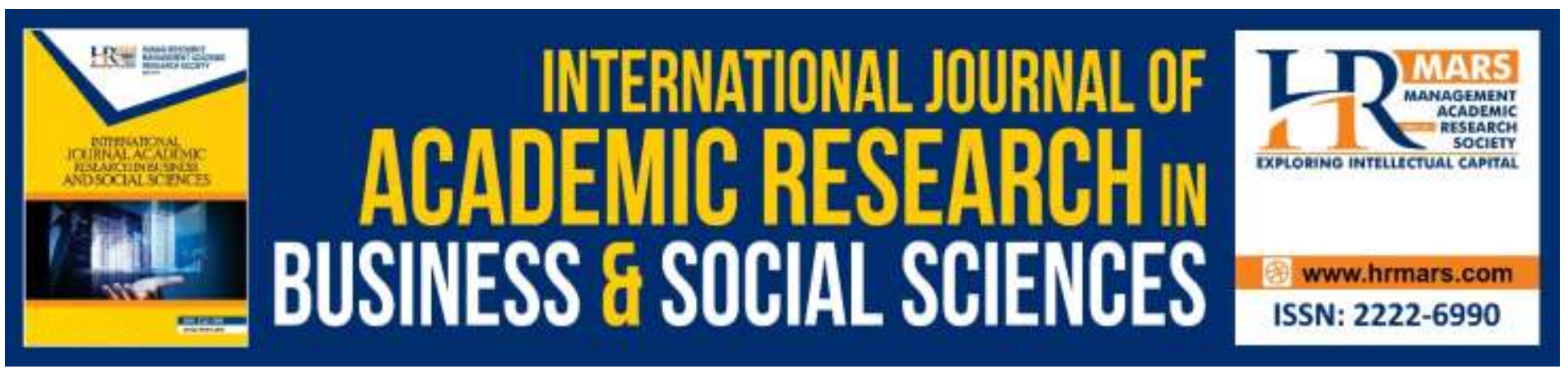

\title{
Forms and Content of Malaysian Indie Theatre in the Development of the Malay Drama
}

\author{
Syarul Azlina, Zolkipli Abdullah \\ Department of Performing Arts, Faculty of Music and Performing Arts, Sultan Idris \\ Education University, Malaysia
}

\begin{abstract}
Theatre development plays an important role in empowering the creative arts industry in Malaysia in line with technological advances. The Malaysian Indie Identity Theatre study in Malay Drama Stage Development is carried out to bring professionals, academics, practitioners and students from across the country to jointly foster the potential of participants in the creative industry. Indie Theatre is a new theatre genre that is evolving in the Malay drama stage. This has indirectly opened a new perspective on the concept of form and content in indie theatre performances. Hence, this study is to find out the form of indie theatre production that is able to attract the audience? The research was able to achieve two objectives, namely to describe the form of Malaysian Indie theatre in the development of the Malay drama and to analyse the identity and contents of the Malaysian Indie theatre. The researcher conducted the study by interviewing four informants who are activists and academics in the theatre field. Subsequently, after analysing the data, the researcher unravelled the form and content with the Identity theory guide to build the identity of the Indie theatre production. The implication of this study is very important as it will guide the knowledge and opportunities to build new innovations in theatre field, add more references to the development of the postmodern Malay drama stage and can enhance the creative industry especially Indie theatre production in line with producing brilliant art practitioners on the basis of the creative industry of the country.
\end{abstract}

Keyword: Identity, Indie Theatre, Malay Stage Drama

\section{Introduction}

Indie theatre is a new genre which is developing greatly in creative arts industry post-millennially. According to B. Coy (1990), the development of indie theatres started in Australia back then in the 1930's following the construction of The Independent Theatre Ltd as a building built to stage smallscale plays by prominent theatre activists led by Dame Doris Fitton. Since then, more theatrical productions started to stage small-scale plays and widely recognized with staging indie theatres. Thus, indie theatrical productions have exhibit new innovations on the forms and contents since small-scale theatres are different than mainstream theatre performances (huge-scale theatres). 
According to Mana Sikana (2017), to recognize the identity, dramatization needs to refer to the forms and textuality. Therefore, in this research, indie theatres are not only a lifestyle or instant theatres, but they have also included the form of the piece and the format of the performances. Due to this, the problem statement of this research will focus on the forms and contents included in the smallscale plays which build the identity of indie theatres. According to researches, the existence of indie theatres in Malaysia started with the staging of Misi, Wangi Jadi Saksi, and followed by Jerjak, Parah, and other performances which keep the same characteristics as in indie theatres. These works went viral in 2006, staged in Theatre Store in Dewan Bahasa dan Pustaka (DBP) and Pentas2, Kuala Lumpur Performing Arts Centre (KLPAC). In Malaysia, indie theatres are usually put into motion by young activists such as Playground Production, Instant Café Theatre Company, Rumah Anak Teater, Revolution Stage, Paradoks Production, MASK Team, Ayaq Hangat Studio, and various other productions. With small spaces, young theatre activists produced their own scripts and productions. According to Harper, P. B. (1994), post-modern creative works are the author's aspirations recognized by social dimensions. Therefore, the research on indie theatres' identity needs to focus on the art so that it can be an added value to new perspectives towards the format of the performances and the highlighted issues conveyed in the performances. Hence, this research is conducted to determine how the forms and contents of indie theatres shaped the identity of indie theatres in the development of Malay stage plays, mainly in Malaysia.

\section{Purpose of the Study}

The purpose of this study is to provide research the forms and content of Indie Theater in Malaysia. The information gained through this study will help to identify the forms and content that built the identity of indie theatres in the development of Malay stage plays.

\section{Methodology}

This research will use qualitative methods such as interviews, literature reviews and observations (recorded plays). The collected data is descriptive. Researcher will use 2 research samples in conducting this research which are the recorded theatre video of Asrama Ra All Star directed by Khairun nazwan Rodzy and Juta-Juta theatre directed by Fasyali Fadzli. These samples will be the data to determine the forms and contents as the identity of indie theatres.Besides, the method of collecting the data is carried out by conducting a field research by interviewing four (4) informants. Researcher will interview four (4) activists who stage indie theatres in Malaysia. The selected informants are Fasyali Fadzly (the founder of Paradoks Production), Khairunazwan Rodzy (the founder of Revolution Stage), Yusuf Bakar (the founder of Bakawalee), and Abdul Rahman Hanapiah or more commonly known as Mana Sikana, an academician figure in post-modern drama. Selecting the informants is perfect since they are prolific activists and owned theatrical production companies in the staging of indie theatres. Meanwhile, the selection of Mana Sikana is based on him being an academician figure in the development of drama and post-modern theatres in Malaysia. Other than that, researcher will also use literature reviews to obtain information and data related to books, articles, newspaper cuts, and journals related to indie theatres and identity theories. Internet sources such as websites, Facebook, blogs, and various others will also be used by the researcher to obtain references and additional data to answer the research questions. 


\section{Findings}

Indie theatre is an increasingly popular genre within the creative arts industry in the development of Malay stage plays. Until today, researcher has identified that many indie theatres have been staged by theatre activists. The staging of indie theatres take place in Theatre Store in Dewan Bahasa dan Pustaka (DBP) and Pentas2, Kuala Lumpur Performing Arts Centre (KLPAC). In Malaysia, indie theatres are usually put into motion by young activists such as Playground Production, Instant Café Theatre Company, Rumah Anak Teater, Revolution Stage, Paradoks Production, MASK Team, Ayaq Hangat Studio, and various other productions. Based on the field research, researcher found out that Theatre Store is a stage location built to give the opportunities to individuals or Malay theatre groups especially the younger generations to produce new works to enliven theatrical activities in Malaysia. In addition, the Store is an alternative space to help and give chances to new theatre activists to make their mark in the industry.According to Musa, S. F. \& Effindie, S. E. (2018), within the years 20032011, more than 150 small-scale theatres had been staged in the Store. Also, according to Omar, A., Amir, M. \& Humairah, F. (2019) in their book entitled Drama dan Teater dalam Pendidikan, after the closing of DBP Store in 2014, small-scale theatre activists started to explore new locations to stage their theatres. The result of this research, some of the selected spaces are Revolution Stage, KOTAK (Five Arts Centre), Studio Stefani (Sanggar Teater Fauziah Nawi), Lot'ng (Three sixty Theatre), Bleen Box and more. Based on the development of the stages, small-scale theatre performances started giving off perspectives in building the identity of Malay indie theatres specifically.

Referring to Kamus Dewan Bahasa Fourth Edition (2001), identity is the characteristics that introduce or distinguish something to others of its kind. This carries the meaning of 'identity' as a trademark that distinguishes itself from another. According to Colhoun, C. (1994) in his book Theory and The Polities Of Identity, in the subtopicThe Value of Difference, he explained that 'identity' is a special feature owned by an individual and motioned to debate, becoming a research sample and contributes to the conflicts in social sciences study. Abdul Rahman Embong (1999); Azman, Shuraimi, \& Yunus, (2018); Jagero et al., (2016); Hayek (2018) stated that 'identity' is something that interacts and relates to various sourcessuch as history, religion, geography, nature, and others which influence humans' behaviour and activities. Based on the definitions of 'identity' mentioned above, research shows that small-scale theatres shaped a new perspective which builds the identity of indie theatres. According to Yde, Matthew (2016), the definition of 'indie theatres' was first introduced by Independent Theatre Motion in Europe, and it was the main influence in modern dramatic literature and theatre modernism. He also stated that small-scale free theatres are committed to free theatres and drama from common conventional limitations. Therefore, the identity of indie theatres started with new groups of theatre activists which searched for opportunities on small stages. Namron (2018), based on his observations, smallscale theatres are a phenomena in the development of indie theatres because they are more prone to minimal ideas, issues, and aesthetical values. His statement shows that issues become the main characteristics in the identity of indie theatres. According to Fasyali (2018), stage usage, budget, management, and small-scale actors and actresses are all contributing factors that influence the issues highlighted in indie theatres.Thus, in renewing the issues in indie theatres, production teams applied critical issues and social conflicts within the society as the identity of indie theatres. 
Based on the findings, research identified the forms in the sample of performance of Juta-Juta Theatre and Asrama Ra All Star which showed that they have small productions, small stage usage for performances, budgets of RM200 for Juta-Juta Theatre and RM500 for Asrama Ra All Star, the duration of each play is only an hour, production team of only 2-5 people, simple storylines, total actors and actresses 2-9 people, the audience consists of amateur theatre activists, and they own small production companies. From the aspect of content, the analysis of research samples clearly show that indie theatres have simple storylines, minimal scenography aspects such as setting, props, costumes, lighting, and music. Therefore, this research concludes that Juta-Juta Theatre and Asrama $\mathrm{Ra}$ All Star have opened new spaces and perspectives towards the activists who withhold the identity of indie theatres.

To sum up, researcher has categorised the identity of indie theatres in Malaysian stage plays is developed from the forms and contents of the performances. The forms of the identity of indie theatres are:
a. Small stages
b. Low cost for staging the play
c. The duration is between 40 minutes to 1 hour and 15 minutes only
d. Use only short and simple stories
e. Total actors and actresses between 2-9 people only
f. Minimal management format
g. Have target audience
h. Own small production companies

The contents of the identity of indie theatres consist of:

a. Themes related to latest social issues and problems

b. Explains a simple storyline

c. Shows a clear and easy concept in every performances

d. Displays only one background

e. Contains simple dialogues and language

f. Easily-understood and identified characters and characterisations

g. Use latest and simple music

h. Have simple but impactful "wow" effect

\section{Conclusion}

The development of indie theatre will be a new phenomenon in the field of literature. The influence of form and content on indie theatre will create an identity for indie theatre. The results of this study will also provide guidance on indie theatre staging policies and can contribute to the development of theatre.

According toWatts, R. (2016), "..key to the development of the independent theatre agreement is the recognition that legally..," and according to Hansel,A. (2017), he stated that "..independent theatre confronted with a free market economy and forced to redefined their place in changing their 
INTERNATIONAL JOURNAL OF ACADEMIC RESEARCH IN BUSINESS AND SOCIAL SCIENCES

Vol. 10, No. 1, Jan, 2020, E-ISSN: 2222-6990 @ 2020 HRMARS

society..". Based on their statements, researcher is able to evaluate the identity of indie theatres as a model with high-impact potentials to open platforms and network in the development of theatres.

\section{Acknowledgement}

This paper is based on the research project entitled 'The Identity of Indie Theatre in the Advancement of Malaysian Plays' The authors would like to extend their gratitude to the Research Management and Innovation Centre (RMIC),Sultan Idris Education University (UPSI) for the University Research Grants (code: 2018-0108-106-01) that helped fund (RM 7,550.00) the research.

\section{References}

Asri, A. (2016). Karya indie bukan main-main. Retrieved from Utusan Online: http://www.utusan.com.my/pendidikan/sastera/karya-indie-bukan-main-main-1.332800

Azman, M. N. Bin, Shuraimi, F. Binti M., \& Yunus, M. Binti M. (2018). Enhancing English Language Learning and Teaching via Qgram (Telegram and Quizlet) Innovation. International Journal of Academic Research in Progressive Education and Development, 7(4), 435-446.

Coy, B. (1990). The significance of the little theatre movement in Sydney with particular reference to the independent theatre, Sydney; University of New South Wales.

Colhoun, C. (1994). Socialtheory and the polities of identity. Cambridge : Blackwell.

Embung A. R. (1999). Identiti dan pembentukan identiti.Jurnal Sains Kemasyarakatan dan Kemanusiaan. Keluaran Khas (55).

Hayek, A. M. A. (2018). The Relationship Between Sales Revenue and Net Profit with Net Cash Flows from Operating Activities in Jordanian Industrial Joint Stock Companies, International Journal of Academic Research in Accounting, Finance and Management Sciences 8 (3): 149-162.

Hamzah, A. W. (2009). Stor Teater DBP Pemangkin Dramatis Muda. Retrieved from Utusan online:www.utusan.com.my/hiburan/stor-teater-dbp-pemangkin-dramatis-muda-1.230752.

Harper, P. B. (1994). Alliance of independent authos (ALKLi) FAQ: about self-publishing\& indie authors, alliance indpendent.com.my.

Hansel, A. (2017). Independent theatre in contemporary Europe, German;Trancript Verlag, Bielefield.

Husin, F. (2007). Teater eksperimental melayu : satu penyelidikan bentuk dan struktur teks dramatik.Pulau Pinang; Universiti Sains Malaysia

Azlina, S., \& Abdullah, Z. (2020). Forms and Content of Malaysian Indie Theatre in the Development of the Malay Drama. International Journal of Academic Research in Business and Social Sciences, 10(1), 209-215.

Jagero, N., Chisedzi, W. K. T., Sithole, N., Shadreck, \& Chitima, S. (2016). The Role of Zimbabwean Museums in Creating National Identity during PostColonial Era: A case study of Zimbabwe Military Museum. Multilingual Academic Journal of Education and Social Sciences, 4(1), 57-64.

Kamus Dewan Bahasa, Edisi keempat. (2001).Kuala Lumpur; Dewan Bahasa dan Pustaka.

Micheal, Z. N. (2009). Indie culture: in pursuit of the authentic autonomous alternative. University of Texas Press P.o Box 7819 Austin.

Musa, S. F., Samsuddin, E. (2018). Konsep minimalis dalam aspek sinografi teater alternatif melayu di stor teater DBP; Kuala Lumpur. Dewan Bahasa dan Budaya 
INTERNATIONAL JOURNAL OF ACADEMIC RESEARCH IN BUSINESS AND SOCIAL SCIENCES

Vol. 10, No. 1, Jan, 2020, E-ISSN: 2222-6990 @ 2020 HRMARS

Omar, A., Amir, M., Humairah, F. (2019).Drama dan teater dalam pendidikan, Perak;Universiti Pendidikan Sultan Idris.

Sikana, M. (2017). Di atas pentas drama melayu pascamoden, Kuala Lumpur; Institut Terjemahan dan Buku Malaysia Berhad.

Yde, M. (2016). Independent theater movement, United Kingdom; Informa UK limited. 